\title{
The Analysis of a Culinary Business Marketing Strategy Through Online Media
}

\author{
A Rizaldi ${ }^{1}$, Y R Fauziah ${ }^{2}$ \\ \{arjuna@email.unikom.ac.id ${ }^{1}$, yulianirestifaa@mahasiswa.unikom.ac.id ${ }^{2}$ \}
}

Fakultas Ekonomi dan Bisnis, Universitas Komputer Indonesia, Indonesia ${ }^{1}$

Fakultas Ilmu Sosial dan Ilmu Politik, Universitas Komputer Indonesia, Indonesia ${ }^{2}$

\begin{abstract}
The purpose of this study is to identify the marketing strategies applied by culinary companies in Bandung through one of the online media. The research method used in this study is a qualitative approach using case study method, data collection techniques that were used are literature study and online data search which would be analyzed according to the method of the case study. The results of this study indicate that the marketing strategy through online media has a good promotional strategy that can compete with other promotional strategies that have different bases. Along with technological advancements, this marketing strategy not only improves the quality of sales and purchases financially but also can build images that are good in the eyes of the public or consumers. This research was conducted by discussing promotional strategies by culinary business companies because a good promotion strategy can affect the increase in company income both in terms of effectiveness and profitability.
\end{abstract}

Keywords: Culinary Business, Promotion Strategy

\section{Introduction}

Observing the expanding of public curiosity in the culinary business that occurred in this millennial era, many people in business began to open their businesses in the culinary field. They do numerous ways and make various innovations to withstand competitions, especially in their marketing strategy which are made to sell or promote their products. In this modern world, online media can be used as one of the tools to execute a business strategy. For example, the usage of the website as a medium to promote their products and attract consumers. Marketing is the first attempt to introduce products to consumers, this is very important because it will be related to the profits that will be gained by the investor. As such, the internet is the right marketing strategy in order to get closer to the public. Lots of product sales are provided by online shops throughout the internet both local and international and from expensive to cheap prices [1]. Magdalena and Sridharan explained that the media campaign is currently being used on the Internet by the company because it is regarded as the main concern that customers will notice its products and is being considered far more effective than advertising using print media [2]. Rendy Indra Susanto stated in Business Development Strategy Analysis at PT. PATRINSAKA that the proper business development strategy that should be implemented in the company is intensity. In the intensive strategy, the company can implement its market development strategy by expanding its marketing area to untouchable areas. Companies can use market penetration strategies by maintaining and improving service quality to customers so that customers are not easily switched to competitor companies [3]. Marketing strategy is one of the main methods to introduce products to the consumers, this is very important because it will be related to the benefits that will be acquired by the company. Marketing strategies will optimally be useful if supported by a plan that is structured internally and externally. Essentially, humans 
as consumers of goods and services aim to fulfill the wishes and necessities of life. This means that consumers are not only buying products or goods in vain but also buying the benefits and usefulness of the product.

Marketing is an organizational function and a series of processes for creating, communicating, and delivering value to customers and also managing relationships in a way that benefits the organization and its stakeholders [4]. Marketing strategy is a mindset that will be used to achieve the goal of marketing itself. The marketing strategy contains specific strategies for the target market which are positioning, marketing mix, and amount of marketing costs. In building a business, this marketing strategy can be organized according to the company's objectives. Mackay and Zundel explain that strategy and tactics are a concept that is often used in business and management [5]. According to Hammouri and Abu, the process of creating a marketing strategy should consider several factors such as products, business locations, and promotions [6]. In order to get maximum marketing results, the process should be planned through a good marketing strategy; There are three stages of planning: testing the current marketing situation including its chances, setting goals, and developing the marketing strategies [7].

The Internet has changed the traditional paradigm from business marketers to business operators. Marketers utilize operational efficiency and effectiveness from internet transactions which can outperform companies that are still using traditional transaction process [8]. The smoothness and ease of conducting mechanical transactions in online business can provide an opportunity to achieve the global market [9]. Online business also facilitates the effort in establishing a cooperative relationship between business partners in the procurement and distribution also in services and goods directly without a broker. This fact will reduce operational costs and increase business margins [10]. Patrutiu Baltes shows that digital marketing has a great interest in the marketing strategies of any company regardless of the sector, size, or country. To remain competitive, companies are forced to exploit the form of marketing that can essentially bring huge profits at low cost [11]. The method used for this research is a qualitative approach to using case study methods, the data collection techniques used in this study are literature studies and online data search, which are then analyzed according to the case study method. The importance of marketing strategies for companies is to help companies explain in detail all marketing-related activities to consumers. This research is done by discussing the advertisement strategy conducted by the culinary business company because it can affect the company's income both in terms of effectiveness and profitability.

\section{Material and Methods}

The method used for this research is a qualitative approach to the case study method by interviewing three peoples who were actively using online media. The data collection techniques used were literature studies and online data search, then analyzed according to the case study method. A case study was a series of scientific activities that were carried out intensively, in detail, and in-depth from an event, program, and activity whether at individual level, group of people, institutions, or organizations whose function is to obtain in-depth knowledge of the event.

\section{Results and Discussion}

The increasingly sophisticated technological developments in this era are making business competition create innovations and marketing strategies to further attract consumers interest [12]. One of the most used marketing strategies in promoting a restaurant is by using social media. Social media marketing like Instagram, Facebook, Twitter, and YouTube has been much choice because of its many users. Besides being able to reach many audiences, social media is also a cheap and effective promotional tool [13]. 
As one of the companies in the culinary business, Justus Steak House is a small business founded by Yudi Boim. Boim is a graduate of STPB 1999, originally selling juice drinks at Bandung Trade Center in August 2005 under the name Justus. By orienting to customer satisfaction and quality of materials, in 2006, Justus tried to sell various kinds of burgers and steaks in Bandung. The new concept to sell burgers and steaks done by Yudi Boim appears to make a positive response from the customer which can be seen by how many outlets of Justus Steak House in Bandung. Until the year 2017, Justus Steak House has 17 outlets consisting of The three brands which are Justus Burger and Steak, Asian Grill, and Justus Steakhouse.

To get more customers and profits, Justus Steak House created a promotional strategy by creating websites and Instagram as a media campaign and attracting more customers. Besides, Justus Steak House also makes promotions so that consumers are interested. In this research, the author will analyze the marketing strategy of Justus Steak House that uses online media, i.e. the website www.justusku.co.id.

The main web displays the latest menu provided by the company to prospective customers which includes food menus, promo, and food locations (Fig. 1).

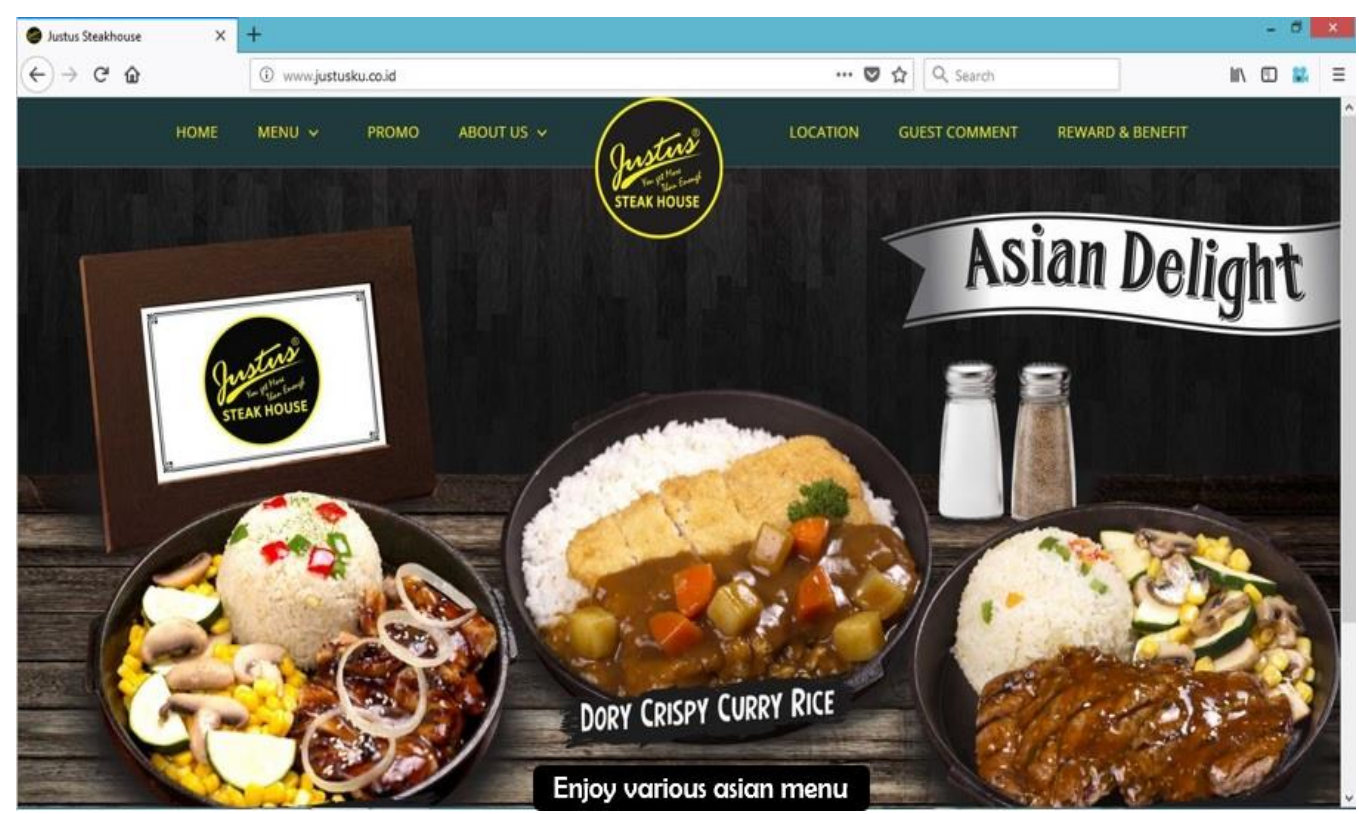

Fig 1. Main menu. This Figure was adapted from www.justusku.com on December 14, 2018.

In the selection menu, the company's food Menu is displayed along with photos of the foods so that consumers can choose the food according to their interests (Fig. 2). 


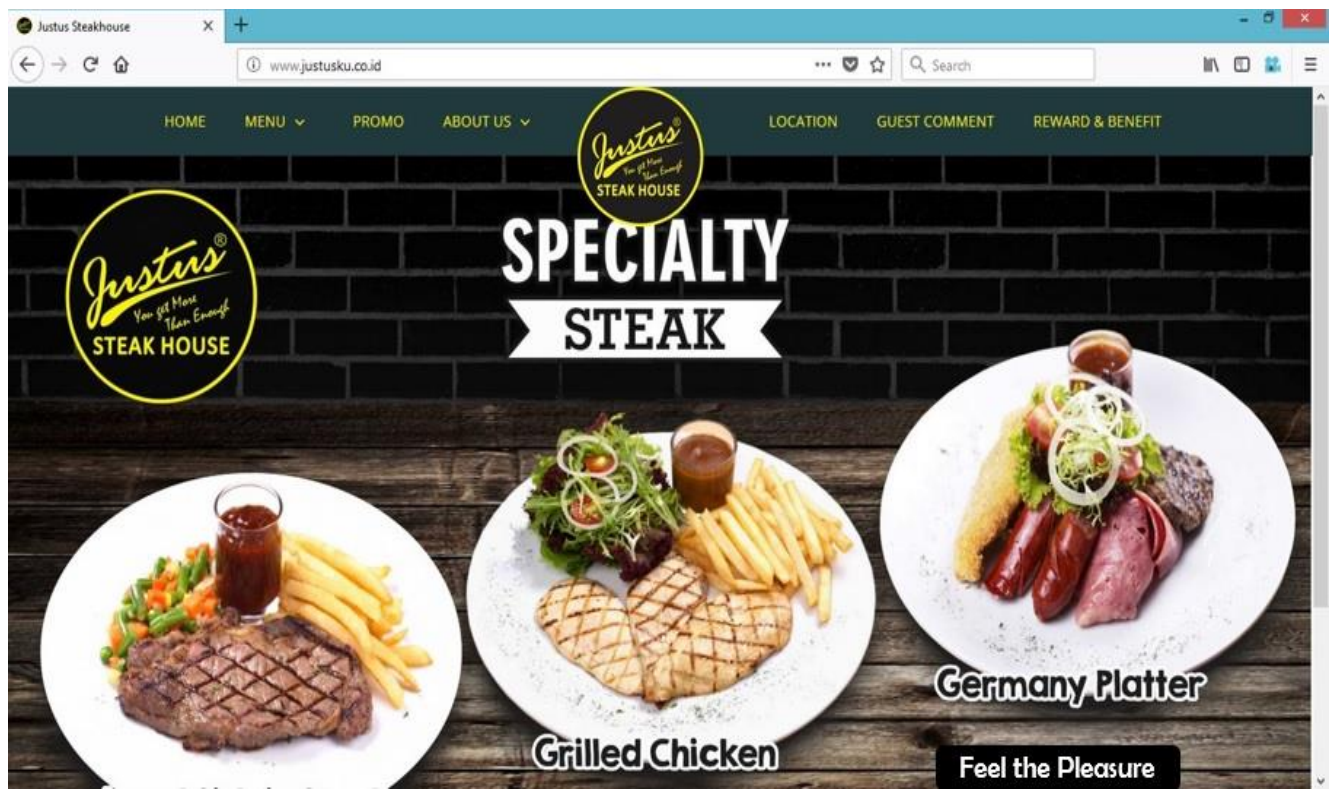

Fig 2. Display of the Food Menu. This Figure was adapted from www.justusku.com on December 14, 2018.

In the promo menu, some of the promos can be obtained by buyers with various terms and conditions in hopes of making consumers interested to come and buy the food (Fig. 3).

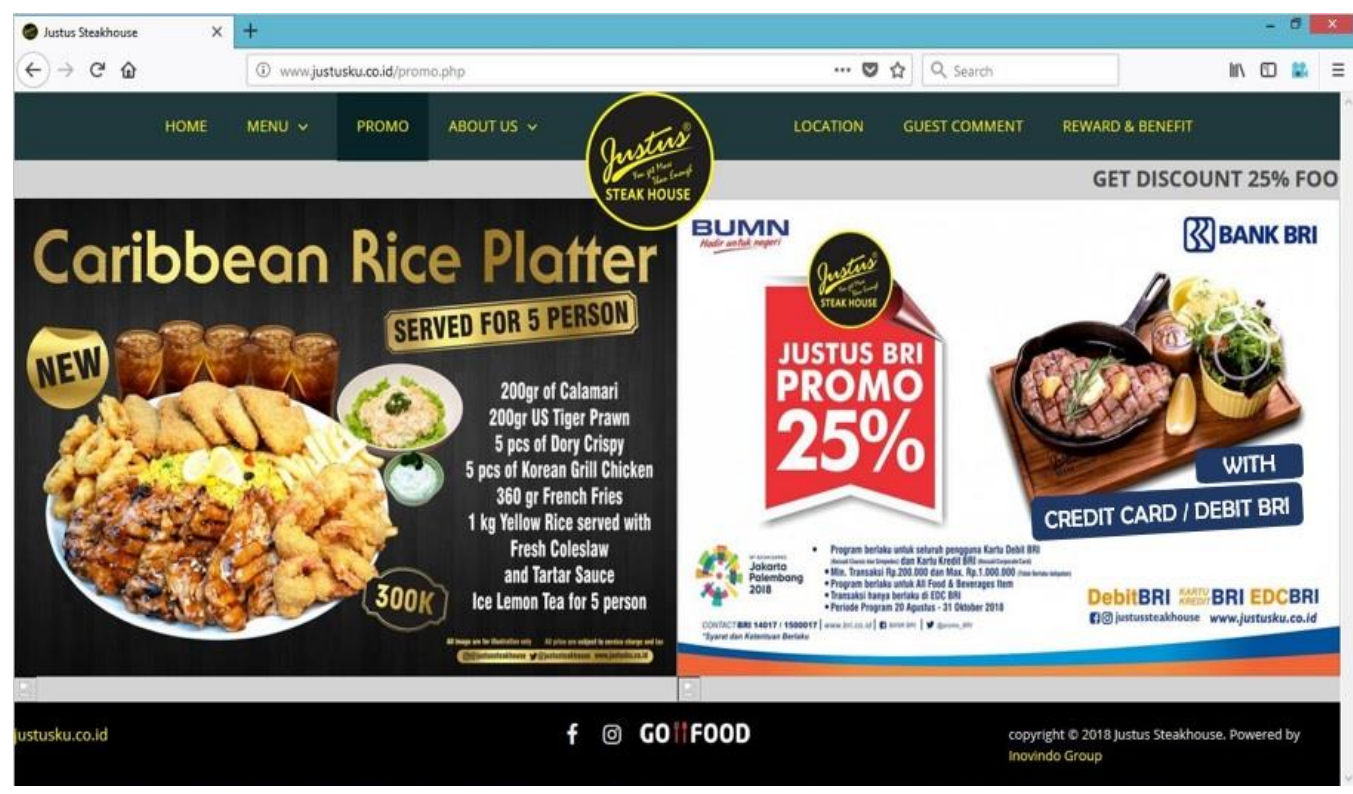

Fig 3. Display of Food Promo. This Figure was adapted from www.justusku.com on December 14, 2018.

Every prospective buyer who wants to know the company's background, including the vision and mission of the company can see on the menu about us. Also, consumers can also see the number of employees owned by the company (Fig. 4). 


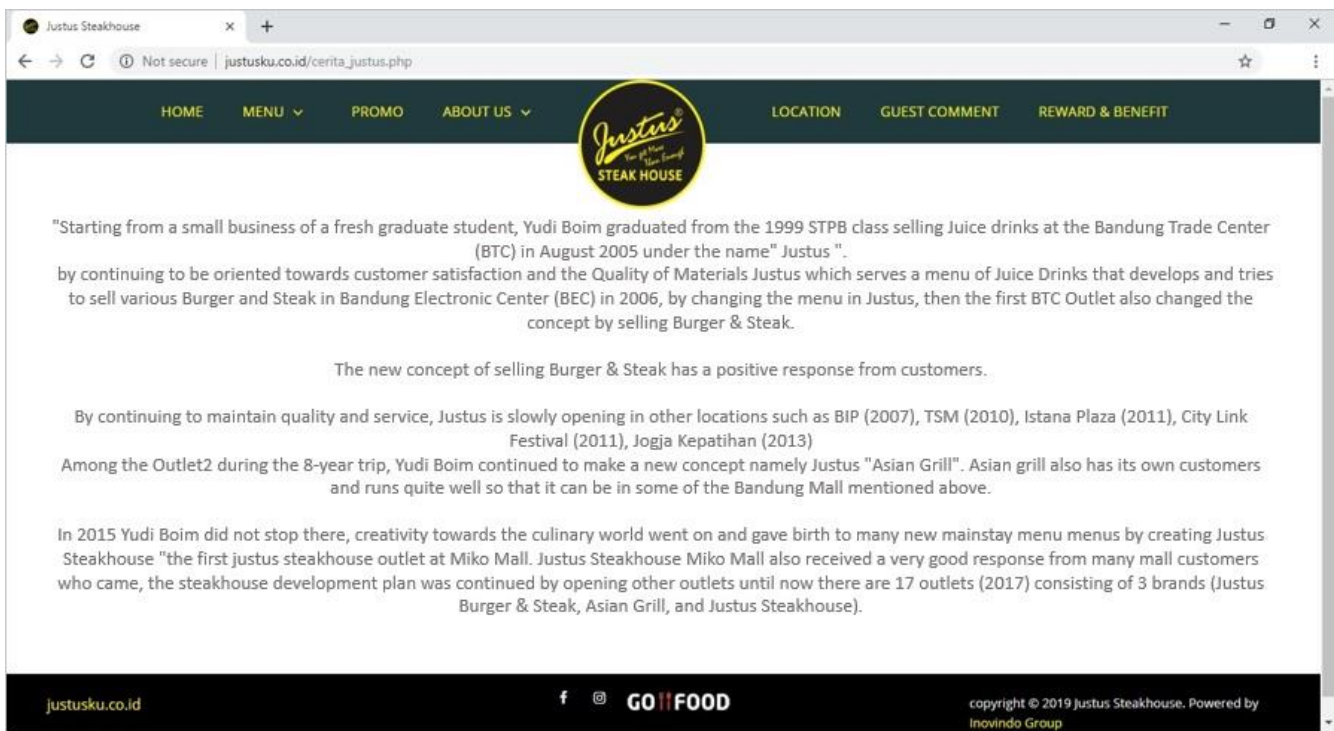

Fig 4. Display of Company Overview. This Figure was adapted from www.justusku.com on December 14, 2018.

Justus Steak House makes a display of the location of its shops with the purpose to makes it easier for potential customers to find the closest food places to their location (Fig. 5).

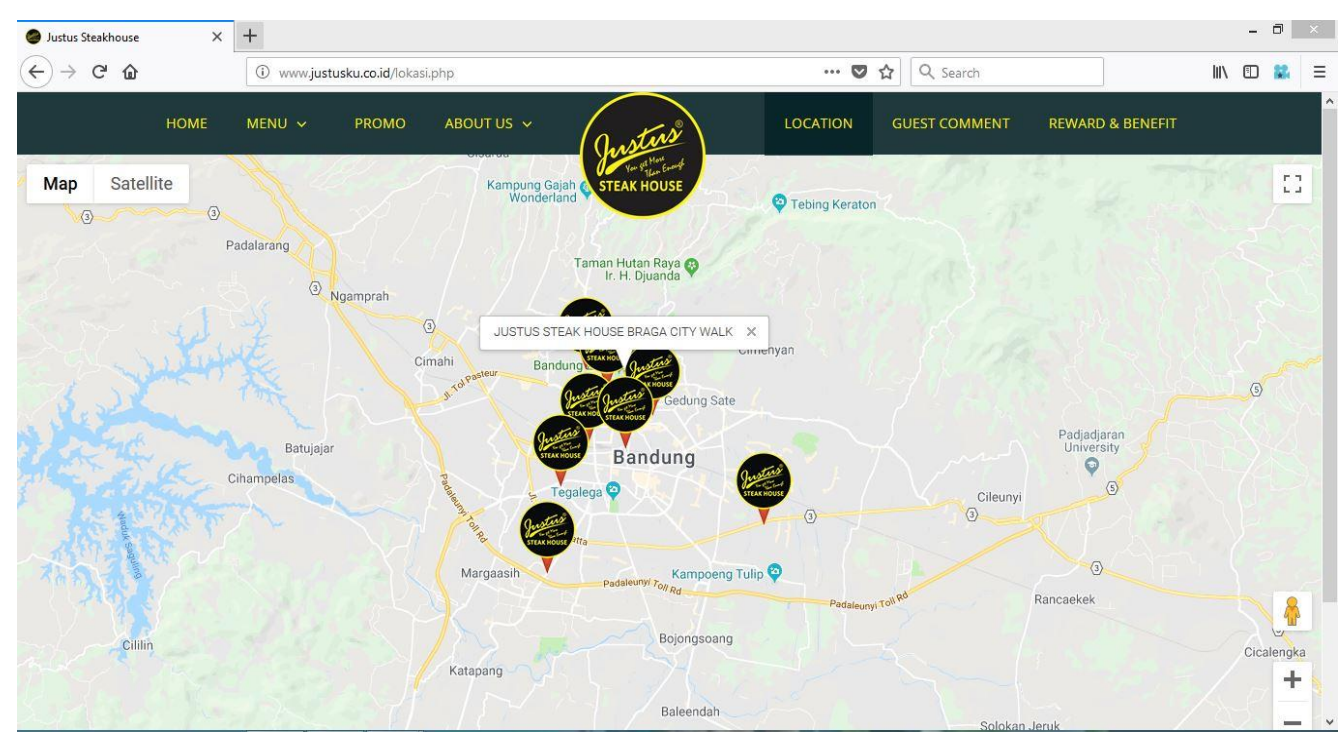

Fig 5. Location Display. This Figure was adapted from www.justusku.com on December 14, 2018.

After enjoying the meal, the buyer may leave comments and suggestions for the company both in terms of food and service. The comment is expected to help the company to improve its services (Fig. 6). 


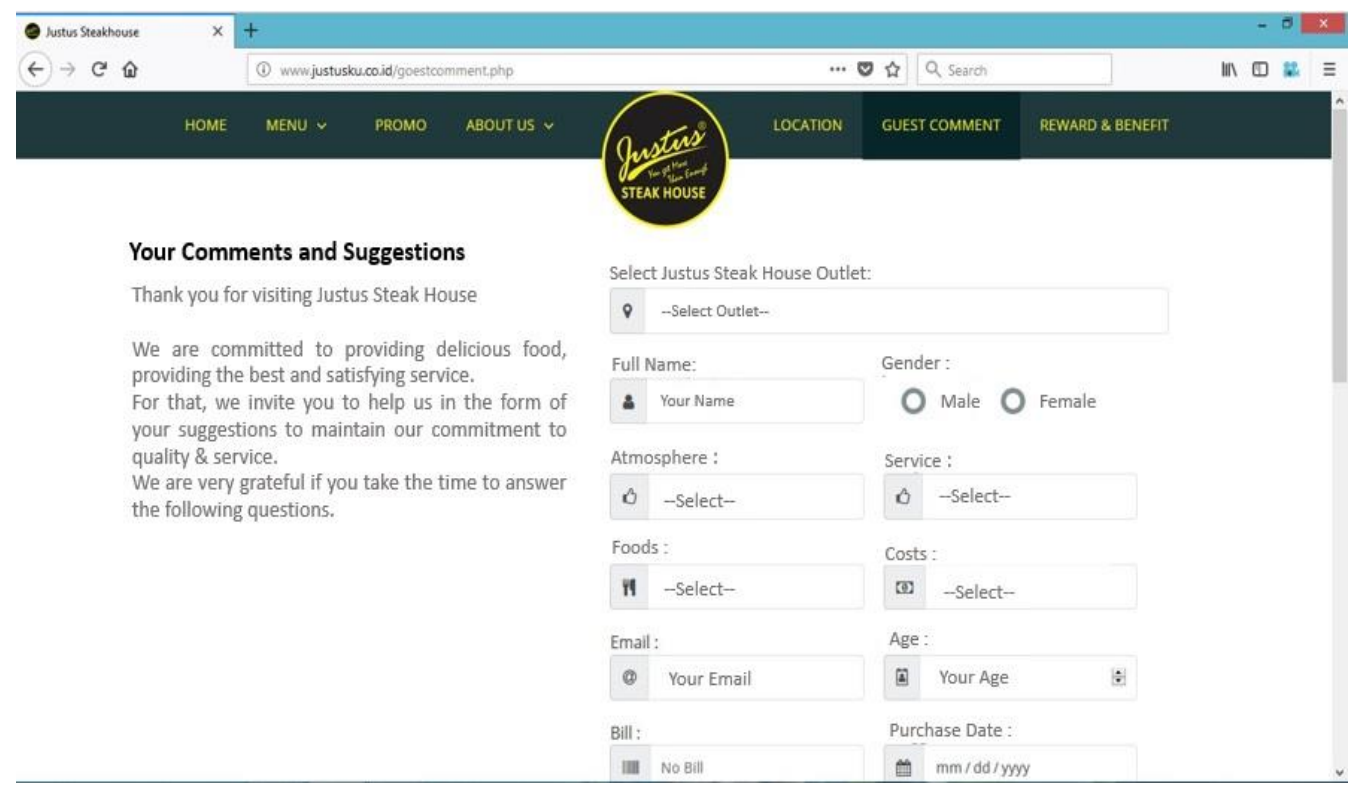

Fig 6. Display of comment form. This Figure was adapted from www.justusku.com on December 14, 2018.

\section{Conclusion}

The development of today's technology has been greatly improved, and one of the Indonesian people's habits since the era of social media is to find a place that offers delicious and inexpensive culinary. This reason is what drives many restaurants including Justus Steakhouse to be passionate about creating the latest ideas, concepts, and innovations by providing promotional strategies in online media such as websites, Instagram, Facebook, and others in order to be easily recognized by the public. In addition to financial benefits, the culinary business companies do not have to bother promoting because buyers have helped indirectly.

\section{References}

[1] R. Anshari, :"Strategi Komunikasi Pemasaran Melalui Media Online dan Tingkat Kepuasan Membeli (Studi Korelasional tentang Strategi Penjualan Produk Fashion melalui Instagram terhadap Kepuasan Membeli Mahasiswa FISIP USU),” 2, pp. 1-10, 2011.

[2] I. O. P. C. Series and M. Science,: "Marketing Strategy of Tourism Package through Design of Webbased Information System on One of Tours and Travel in Bandung Marketing Strategy of Tourism Package through Design of Web-based Information System on One of Tours and Travel in Bandung," 4, 143-56. 2018

[3] P. M. Bisnis, P. S. Manajemen, U. K. Petra, and J. Siwalankerto,: "Strategi Pengembangan Bisnis Pada PT. Timur Jaya Panel, ” 4(1), pp. 693-701, 2016.

[4] Liang T P, Ho Y T, Li Y W, and Turban E.: What drives social commerce: The role of social support and relationship quality. Int, 2, 231-43. (2011).

[5] Mackay D, \& Zundel M.: Recovering the Divide: A Riview of Strategy and Tactics in Business and Management. Internasional Journal of Managemen Reviews, 19(2) pp. 175-94. 2017

[6] Hammouri Q, Abu-Shanab E. :Exploring Factors Affecting Users' Satisfaction Toword E Learning Systems. Internasional Journal of Information and Communication Technology Education (IJICTE), 14(1) pp. 44-57. 2018.

[7] Dr. Ir. Eddy Soeryanto Soegoto.: Entrpreneurship Menjadi Pembisnis Ulung edisi revisi. Penerbit Gramedia: Jakarta. 2, 112-41. 2014.

[8] Sharma A.: Trends in Internet-based business-to-business marketing. Idustrial marketing management, 31(2), pp. 77-84. (2002)

[9] Cho V et.al. : An Integrative Framework for Customizations On Satisfaction: The Case of an Online Jewelry Business In China. Journal of Service and Management, 7, pp. 39-44. 2014 
[10] Ahmed B et.al.: The Intelligence of E-CRM Applications and Approaches On Online Shopping Industry. Internasional Journal of Innovation and Scientific Research, 12(1), pp.213-16. 2014

[11] Patrutiu-Baltes L. :Inbound marketing-the most important digital marketing strategy. Bulletin of the Transilvania University of Brasov. Economic Sciences. Series V, 9(2), pp. 61. 2016

[12] Berry, L. L.: Relationship marketing of services - growing interest, emerging perspectives. Journal of the Academy of marketing science, 23(4), 236-45.

[13] Kirtiş, A. K., \& Karahan, F.: (2011). To be or not to be in social media arena as the most costefficient marketing strategy after the global recession. Procedia-Social and Behavioral Sciences, 24, 260-8. (1995). 